\title{
Revision of the New World bee fly genus Heterostylum Macquart (Diptera, Bombyliidae, Bombyliinae)
}

\author{
André Mallemont Cunha ${ }^{1}$, Carlos José Einicker Lamas ${ }^{2,3}$ \& Márcia Souto Couri1 ${ }^{1,3}$
}

\begin{abstract}
'Museu Nacional, Quinta da Boa Vista, São Cristóvão, 20940-040, Rio de Janeiro-RJ, Brazil. a_mcunha@ yahoo.com.br ${ }^{2}$ Museu de Zoologia da Universidade de São Paulo, Avenida Nazaré, 481, Ipiranga, 04263-000, São Paulo-SP, Brazil. einicker@usp.br ${ }^{3}$ Conselho Nacional de Desenvolvimento Científico e Tecnológico (CNPq) fellowship.
\end{abstract}

\begin{abstract}
Revision of the New World bee fly genus Heterostylum Macquart (Diptera, Bombyliidae, Bombyliinae). The genus Heterostylum Macquart and five Neotropical species (H. ferrugineum (Fabricius, 1805), H. hirsutum (Thunberg, 1827), H. rufum (Olivier, 1789), H. haemorrhoicum (Loew, 1863) and H. pallipes Bigot, 1892) are redescribed. The other species, recently redescribed or described are only diagnosed, except for $H$. deani Painter, 1930, whose spermathecae are described and illustrated for the first time. The main characters of the external morphology were photographed and the male genitalia and female spermathecae illustrated. An identification key to all included species is also presented.
\end{abstract}

KEYWORDS. Key; morphology; taxonomy.

RESUMO. Revisão do bombylideos do gênero Heterostylum Macquart do novo mundo (Diptera, Bombyliidae, Bombyliinae). O gênero Heterostylum Macquart e cinco espécies Neotropicais (H. ferrugineum (Fabricius, 1805), H. hirsutum (Thunberg, 1827), H. rufum (Olivier, 1789), H. haemorrhoicum (Loew, 1863) e H. pallipes Bigot, 1892) são redescritas. As demais espécies recentemente redescritas ou descritas tem sua diagnose apresentada, com exceção de $H$. deani Painter, 1930, cuja espermateca foi descrita e ilustrada pela primeira vez. Os principais caracteres da morfologia externa foram fotografados e a genitália masculina e espermateca feminina ilustradas. Uma chave de identificação para todas as espécies também é apresentada.

PALAVRAS-CHAVE. Chave; morfologia; taxonomia.

The genus Heterostylum Macquart contains medium sized species $(10-15 \mathrm{~mm})$ characterized by a robust body covered with long pile and by an indented hind margin of the eye. It presently contains 14 New World species, nine of them occuring in the Neotropical region: H. bicolor (Loew, 1861); $H$. duocolor (Painter \& Painter, 1974); H. evenhuisi Cunha \& Lamas, 2005; H. ferrugineum (Fabricius, 1805); H. haemorrhoicum (Loew, 1863); H. hirsutum (Thunberg, 1827); H. maculipennis Cunha \& Lamas, 2005; H. pallipes Bigot, 1892 and H. rufum (Olivier, 1789); five in Nearctic: H. croceum Painter, 1930; H. deani Painter, 1930; H. engelhardti Painter, 1930; H. helvolum Hall \& Evenhuis, 1981 and H. robustum (Osten Sacken, 1877).

Macquart (1848) erected the genus Heterostylum to include one species from Brazil: $H$. flavum. This species was later considered as junior synonym of $H$. hirsutum by Painter \& Painter (1974). Painter (1930) described three new Nearctic species $(H$. deani, H. croceum and $H$. engelhardti) and also presented an identification key to ten North American species. Painter \& Painter (1974) presented notes about the types deposited at European and United States Museums, and redescribed the genus and three species: $H$. ferrugineum, $H$. hirsutum and $H$. rufum. Hall \& Evenhuis (1981) redescribed the genus and the Nearctic species (H. croceum, H. deani, $H$. engelhardti and $H$. robustum), described $H$. helvolum and presented an identification key to them. Evenhuis \& Greathead (1999) placed Heterostylum among the Bombyliini (Bombyliinae) and considered 12 valid species (seven
Neotropical and five Nearctic). Cunha \& Lamas (2005) presented an identification key to the Brazilian species and described two new ones: H. evenhuisi and H. maculipennis.

The authors redescribed the genus Heterostylum Macquart and five known Neotropical species (H.ferrugineum, $H$. hirsutum, H. rufum, H. haemorrhoicum and H. pallipes). The main characters of the external morphology were photographed and the male genitalia and the female spermathecae were described and illustrated. The spermathecae of $H$. deani, a Nearctic species, is also described and illustrated. An identification key to all included species was elaborated including the two species recently described by Cunha \& Lamas (2005): H. evenhuisi and H. maculipennis; the original descriptions of $H$. bicolor and H. duocolor and the Nearctic species redescriptions of Hall \& Evenhuis (1981). The dichotomies referring to the Nearctic species and the diagnosis for them were based in Hall \& Evenhuis (1981).

Despite the predominance of color characters for the identification of the species, it was possible to find some important characters, especially in the wings, that can be useful for the segregation of the species and can be tested in a future phylogenetic study.

\section{MATERIALAND METHODS}

The material studied is deposited in the collections of the Museu Nacional, Universidade Federal do Rio de Janeiro, Rio de Janeiro, Brazil (MNRJ), Museu de Zoologia da Universidade 
de São Paulo, São Paulo, Brazil (MZSP), Departamento de Zoologia, Universidade Federal do Paraná, Paraná, Brazil (DZUP), Museu Paraense Emílio Goeldi, Pará, Brazil (MPEG) and The Natural History Museum (BMNH), London, England.

It was not possible to redescribe two Heterostylum species (H. bicolor and H. duocolor) as the types are missing or destroyed and no other identified material was found in the studied collections.

\section{Key to Heterostylum species}

1- Dorsum of abdomen with predominant dark brown hairs (Figs. 8, 10, 12, 14); scape dark brown .................... 2 Dorsum of abdomen with predominant light brown, yellow or golden hairs (Figs. 9, 11, 13); scape dark brown, light brown, brownish-red or yellow . ... 6

2- Wing, light brown with dark brown base (Fig. 7) or brown at base and around veins (Fig. 5); mesonotum with golden hairs on dorsum and yellowish-brown laterally

Wing, light brown at extreme base (Fig. 3); thorax not as above

3- Wing, light brown with dark brown base; palpus yellow with dark brown apex; R4 slightly sinuous, almost straight and $\mathrm{r}-\mathrm{m}$ crossvein at $1 / 2$ of discal cell (Fig. 7); abdominal tergite $\mathrm{V}$ with dark brown hairs and spot of yellow hairs on center (Fig. 14) [Argentina; Brazil: Acre, Espírito Santo, Goiás, Mato Grosso, Maranhão, Pará, São Paulo; Guatemala; Guiana; Mexico: Tabasco; Peru; U.S. Virgin Is.] H. rufum

Wing, brown at extreme base and around veins; palpus brown; R4 conspicuously sinuous and r-m crossvein at apical half of discal cell (Fig. 5); abdominal tergite $\mathrm{V}$ with dark brown hairs (Fig. 12) [Brazil: Rio de Janeiro, Santa Catarina, São Paulo] H. maculipennis

4 Dorsum of abdomen with dark brown hairs and long orange hairs laterally (Fig. 10); abdominal tergite I and thorax with dark brown hairs; [Cuba; Dominican Republic; Haiti] H. haemorrhoicum

Abdomen not as above; abdominal tergite I with yellow hairs, thorax with yellow or light brown hairs

5- Abdomen with dark brown hairs and spots of yellow hairs on tergites II, III and laterally on IV (Fig. 8); scutellum brown; frons of females with two polished dark brown circular areas and dark brown hairs [Brazil: Bahia, Ceará, Goiás, Pará, Pernambuco, Rio Grande do Norte, São Paulo] .... H. evenhuisi

Abdomen with dark brown hairs, without yellow spots; scutellum rufous; frons with dark brown hairs, females without the two polished dark brown circular areas [Cuba]..... H. bicolor
6- Abdomen with 3 dark brown spots on tergite II and dark brown stripe on tergites III, IV and V; scape rufous [Argentina] H. duocolor

Abdomen not as above; scape yellow, light brown or dark brown ...... 7

7- Dorsum of abdomen with dark brown, brown or browntipped hairs 8

Dorsum of abdomen without dark brown, brown or brown-tipped hairs 14

8- Dark colored hairs on abdominal dorsum entirely homogeneous tinted

Dark hairs on abdominal dorsum not entirely homogeneous tinted, darker on apical half, or less . 13

9- Antennae entirely dark brown; abdomen with golden hairs, a stripe of dark brown hairs on tergites II, III and dark brown hairs on apex [USA: Colorado, Kansas, Wyoming] ....................................................... H. deani

Antennae with scape light brown or yellow; abdomen not as above 10

10- Palpus yellow with dark brown apex or brown with dark brown apex 11

Palpus entirely yellow or brown ..................................... 12

11- Abdomen with yellow hairs and stripe of dark brown hairs on center of tergites (Fig. 11); palpus yellow with dark brown apex; mesonotum with dark brown hairs on dorsum and yellowish-brown laterally; r-m crossvein at apical half of discal cell (Fig. 4) [Argentina: La rioja; Brazil; Colombia; Paraguay; Venezuela: Federal District] H. hirsutum

Abdomen with yellowish-brown and dark brown hairs on center of tergites III and IV (Fig. 13); palpus brown with dark brown apex; mesonotum with yellowishbrown hairs; r-m crossvein at $1 / 2$ of discal cell (Fig. 6) [Dominican Republic; Haiti] . H. pallipes

12- Abdomen with golden hairs and stripe of dark brown hairs on center of tergites (Fig. 9); palpus yellow; scutellum light brown [Bolivia: El Carmen; Brazil: Bahia, Ceará, Goiás, Mato Grosso, Roraima, São Paulo; British Virgin Is.; Paraguay; Porto Rico; U.S. Virgin Is] H. ferrugineum

Abdomen with dark brown and sparse white and yellowish-white hairs; palpus brown; scutellum rufous [Canada: Alberta; Mexico: Baja California Norte, Baja California Sur, Coahuila de Zaragoza, Guerrero, Morelos, Nuevo León, Puebla, Sinaloa, Sonora, Tamaulipas; USA: Arizona, Oklahoma, Oregon, Texas, Utah] H. robustum

13- Body with yellow hairs; scape dark brown [Mexico: Sinaloa, Sonora, Tamaulipas, Zacatecas] .. H. helvolum 
Body with white or pale yellowish-white hairs; scape flavotestaceous [USA: Arizona, California, Texas, Utah] H. engelhardti

14- Body with white to very pale yellowish hairs

H. engelhardti

Body with darker yellow hairs [USA: Colorado, Kansas, Missouri, New Mexico, Texas] ..... H. croceum

\section{Genus Heterostylum Macquart, 1848}

Heterostylum Macquart, 1848: 195 [description]; Hull, 1973: 138-140 [redescription]; Hall \& Evenhuis, 1981: 162 [coments], 176 [key to Nearctic species]. Type species: Heterostylum flavum Macquart, 1848 [= Tanyglossa hirsuta Thunberg, 1827], by original designation.

Comastes Osten Sacken, 1877: 256 [description]. Type species: Comastes robustus Osten Sacken, 1877, by monotypy. [Preoccupied by Jan, 1863.]

Unduloptomyia Evenhuis, 1978: 247. New name for Comastes Osten Sacken.

Heterostilum, incorrect original spelling of Heterostylum [Macquart, 1848: 231].

Head: as wide as or wider than thorax, with dense pile; holoptic males; eyes with an indented hind margin; ocellar tubercle with sparse bristles, anterior ocellus separated from the posterior ones by a transverse row of bristles (Fig. 15); face smoothly projected; antennae dark brown, scape with a great color variation and long bristles, usually twice as long as pedicel; pedicel with short bristles; flagellum dark brown, usually longer than the two basal segments combined, with one flagellomere and an apical style; proboscis dark brown, projecting beyond the oral margin by $2 / 3$ to $5 / 6$ of its length.

Thorax: mesonotum dark brown, with dense pile; scutellum with pile and bristles on posterior margin; supra alar callus with sparse strong bristles and postalar callus with a row of strong bristles; anepisternum and katepisternum with long hairs.

Legs: slender with fine pile; femur III with a row of dark brown bristles in the anteroventral surface and small dark brown bristles in the apex of dorsal surface; tibiae and tarsi with scattered dark brown bristles; pulvilli as long as to $1 / 2$ as long as claws.

Wing: hyaline with at least the base pigmented; M1 joining R5 exactly at or sometimes only a little far from the point of origin of R4; R4 conspicuously or slightly sinuous, almost straight; the discal cell ends exactly in the intersection point of $\mathrm{M} 2$ and $\mathrm{M} 1 ; \mathrm{r}-\mathrm{m}$ crossvein at $1 / 2$ or apical half of discal cell and cup cell openning on wing margin by the $1 / 2$ to the same length of the r-m crossvein.

Abdomen: wider than thorax, densely covered with pile.

Genitalia: in lateral view with gonocoxa elongated with rounded apex; epiphallus long, L-shaped apically; aedeagus thin with wide base, sometimes pointed, apex; gonostylus robust, with apical beak-like process.

Spermathecae: elliptical or circular; furca "U" or "M" shaped, with lateral processes enlarged apically; spermathecal ducts usually twice as long as sperm pump, uniting to form a short common spermathecal duct; sclerotized collars reduced.

Heterostylum croceum Painter, 1930

Heterostylum croceum Painter, 1930: 6 [description]; Painter \& Painter, 1965: 411 [catalogue]; Hull, 1973: 140 [list of species] Hall \& Evenhuis, 1981: 163 [redescription], 176 [key to Nearctic species]; Evenhuis \& Greathead, 1999: 156 [catalogue].

Diagnoses: Male - Mesonotum black; thorax with pale yellow hair, lighter on pleurae. Legs flavotestaceous, with tibiae and tarsi darker than femora, tips of tarsi black. Hyaline wing, slightly tinted with brown at extreme base, alula brown. Abdominal dorsum black, entirely yellow pilose.

Distribution: USA: Colorado, Kansas, Missouri, New Mexico, Texas.

\section{Heterostylum deani Painter, 1930}

(Fig. 24)

Heterostylum deani Painter, 1930: 5 [description]; Painter \& Painter, 1965: 411 [catalogue]; Hull, 1973: 140 [list of species]; Hall \& Evenhuis, 1981: 166 [redescription], 176 [key to Nearctic species]; Evenhuis \& Greathead, 1999: 156 [catalogue].

Diagnoses: Female - Mesonotum black, golden-yellow pilose and tomentose. Legs ferruginous, with femur I darker on basal half. Wing largely hyaline, but base and alula brown; R4 conspicuously sinuous; $r-m$ crossvein at apical half of discal cell. Abdominal tergum black, golden-yellow pilose and tomentose, with black tomentum across base of segment II, expanded medially and in middle of base of segments III and IV; sides of abdomen with black hair on segments II and III, and a few black hairs on segment IV.

Spermathecae (Fig. 24): furca "U" shaped, lateral processes with enlarged and pointed apex; spermathecae elliptical, 2/3 longer than wide, with well delimited base and longitudinal axis about $1 / 3$ length of sperm pump; spermathecal ducts twice as long as sperm pump, uniting to form a short common spermathecal duct; sperm pump placed near apical half of spermathecal duct; sclerotized collars reduced.

Examined Material: Paratypes. USA, Kansas, 25-VIII-1975, 1 female, R.H. Painter; deposited in BPBM; Kansas, 9-VIII-1921, 1 females, R.C. Smith; deposited in BPBM.

Notes: R4 appears slightly sinuous, almost straight in the illustration of Hall \& Evenhuis (1981).

Distribution: USA: Colorado, Kansas, Wyoming.

\section{Heterostylum engelhardti Painter, 1930}

Heterostylum engelhardti Painter, 1930: 7 [description]; Painter \& Painter, 1965: 411 [catalogue]; Hull, 1973: 140 [list of species]; Hall \& Evenhuis, 1981: 168 [redescription], 176 [key to Nearctic species]; Evenhuis \& Greathead, 1999: 156 [catalogue]. 
Diagnoses: Female - Scape flavotestaceous; palpus short, testaceous, with pale yellow hair. Notum entirely pale yellow pilose and tomentose. Legs largely flavotestaceous, with last two tarsal segments black. Wing largely hyaline, with costal margin and extreme base lightly brownish. Abdomen entirely yellow pilose and tomentose.

Notes: This species is very similar to $H$. croceum, but can be distinguished by the presence of brown-tipped hairs on abdomen.

Distribution: USA: Arizona, California, Texas, Utah.

\section{Heterostylum evenhuisi Cunha \& Lamas, 2005}

(Figs. 1;8)

Heterostylum evenhuisi Cunha \& Lamas, 2005: 25 [description], 24 [key to Brazilian species].

Diagnoses: Male - Mesonotum dark brown, with yellowishbrown hairs dorsally and yellowish-white laterally. Legs brown, femur with apex of dorsal surface dark brown. Wing hyaline except for the brown base; R4 conspicuously sinuous; $r-m$ crossvein at $1 / 2$ of discal cell. Abdomen with tergite I dark brown with yellowish-white hairs; tergites II and III dark brown, with dark brown hairs and two light brown lateral spots, with yellow hairs; tergite IV dark brown, with dark brown hairs on central $1 / 3$ and light brown, with yellow hairs on lateral $1 / 3$; tergites $V$ and VI dark brown with dark brown hairs.

Notes: H. evenhuisi share a very similar color pattern of tergites with $H$. maculipennis but can be easily segregated from it by the color pattern of wing, which in the former is hyaline except for the brown base (Fig. 1). This character is shared by all other species, but $H$. rufum has this tinted wing base with bands of different colors (Fig. 7) and tergite V with yellow hairs on the center (Fig. 14) whereas it is entirely covered by brown hairs on H. evenhuisi (Fig. 8). From H. ferrugineum, it differs by the general body color, which is yellow in this species and from $H$. hirsutum it can be distinguished by the entirely brown palpus and also by the color pattern of hairs on abdomen (Fig. 11).

One specimen shows R4 slightly sinuous, almost straight.

Examined Material: Holotype male: BRAZIL, Ceará: Limoeiro, VI - 1940, Shannon \& Alves (26.494) (MZSP); Paratypes. BRAZIL, Pará: Castanhal, VII-1964, 1 female, Sebastião Laroca (DZUP); Bragança, 14-VIII-1977, 3 females, W. L. Overal (MPEG); Ceará: Limoeiro, VI - 1940, 1 male (26.486), 1 female (26.488), Shannon \& Alves (BPBM); 2 males (26.490 and 26.492), 5 females (26.485, 26.487, 26.489, 26.491 and 26.493), Shannon \& Alves; Russas, II1940, 1 female (26.506), Shannon \& Alves (MZSP); Rio Grande do Norte: Ceará Mirim, X-1940, 1 female (26.541), D. Alves; (MZSP); Pernambuco: Petrolina, VII-1974, 5 females, N. Papavero (MZSP); Goiás: Miranorie, BR 14, III -1965, 1 male, 1 female, L. Gomes (MPEG); Bahia: Cachoeira de Paulo Afonso, Rio São Francisco, 11VII-1951, 1 male (954) (MNRJ); São Paulo: Batatais, III-1943, 1 male (26.434), 2 females (26.451 and 26.435), A. Stafuzza; IV-1945, 1 male (26.419), Pde. Pereira (MZSP); Tamoio, XII-1944, 2 males (26.513 and 26.514), M. Barreto (MZSP).
Distribution: Brazil: Bahia, Ceará, Goiás, Pará, Pernambuco, Rio Grande do Norte, São Paulo.

\section{Heterostylum ferrugineum (Fabricius, 1805)}

(Figs. 2; 9; 16; 17; 25)

Bombylius ferrugineus Fabricius, 1805: 132 [description].

Heterostylum ferrugineum; Painter, 1930: 2 [redescription]; Hull, 1973: 140 [list of species]; Painter \& Painter, 1974: 22 [redescription and comments on types] ; Painter et al., 1978: 5 [catalogue]; Evenhuis \& Greathead, 1999: 156 [catalogue]; Cunha \& Lamas, 2005: 24 [key to Brazilian species].

Male: Body length: 14.5 - 15.1mm; wing length: 14.6 $15.5 \mathrm{~mm}$.

Head: holoptic, frons dark brown and gray pollinose, with brown hairs; ocellar tubercle dark brown and gray pollinose, with sparse dark brown bristles; face gray pollinose, smoothly projected, with yellowish-white hairs; oral margin and genae with yellowish-white pile; antennae with two apical segments dark brown, scape light brown with long dark brown bristles, twice as long as pedicel; pedicel with short dark brown bristles on outer surface; flagellum dark brown, twice as long as scape, with one flagellomere and an apical style; proboscis dark brown projecting beyond the oral margin by $2 / 3$ of its length; palpus yellow, 1/5 of the proboscis length, with yellow hairs; occiput light yellow and white pollinose with yellow hairs on the upper half and white on the lower one.

Thorax: mesonotum dark brown, with golden hairs dorsally and laterally, scattered brown hairs; scutellum light brown with golden pile and golden bristles on posterior margin; supra alar callus with sparse strong yellowish-brown bristles and postalar callus with a row of strong yellowish-brown bristles; pleurae light brown and gray pollinose; anepisternum entirely covered by long yellow hairs; katepisternum with yellow hairs on the anterior half; anepimeron, meropleurite and laterotergite bare; metepisternum with yellow hairs; calypter with tuft of yellowish-red hairs; halter stem light brown and knob yellowish-white.

Legs: yellowish-brown with anterior apex darker; coxae gray pollinose with yellow pile; femora with dark brown apex, dark brown scales on apical 2/3 of anterior surface; femur II with one or two dark brown bristles in the anteroventral surface; femur III with a row of dark brown bristles on apical 2/3 of anteroventral surface and small dark brown bristles on apex of dorsal surface; tibiae with dark brown apical bristles; tibiae I and II and tarsi I and II with sparse dark brown bristles; tibiae III and tarsi III covered by dark brown bristles; tarsi with the three apical tarsomeres darker than the others; pulvilli light brown $1 / 2$ as long as claws.

Wing (Fig. 2): hyaline except for the yellow base and light brown alulae; the yellow area includes costal cell, basal 1/3 of br, bm, anal and axilary; R4 slightly sinuous, almost straight; r$\mathrm{m}$ crossvein at apical half of discal cell and cup cell open on wing margin by $2 / 3$ the length of the $r-m$ crossvein.

Abdomen: tergites light brown with dark brown "V" shaped spots; tergites covered with golden hairs and a stripe 

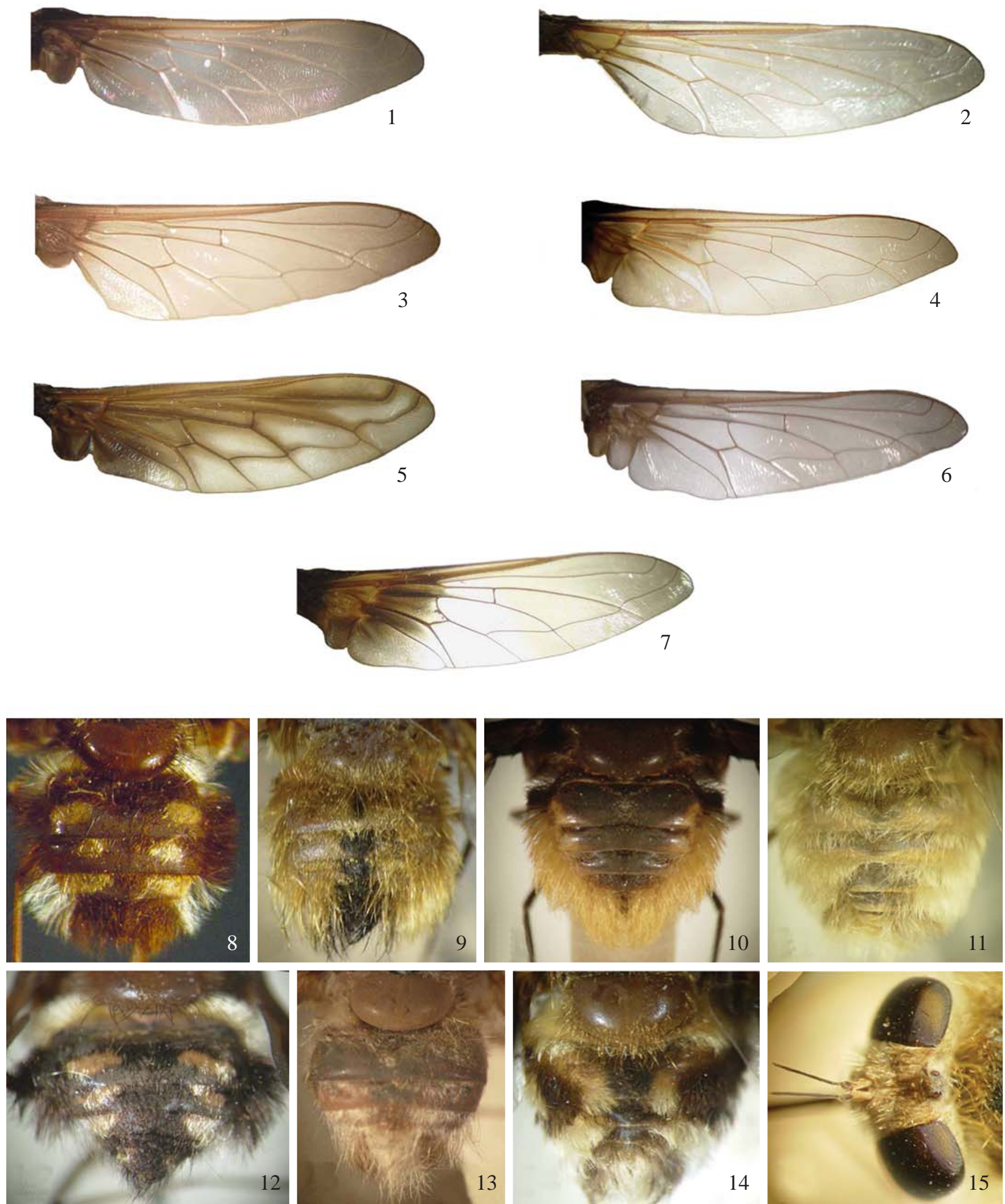

Figs. 1-15. 1-7. Wing: (1) Heterostylum evenhuisi Cunha \& Lamas, 2005; (2) Heterostylum ferrugineum (Fabricius, 1805); (3) Heterostylum haemorrhoicum (Loew, 1863); (4) Heterostylum hirsutum (Thunberg, 1827); (5) Heterostylum maculipennis Cunha \& Lamas, 2005; (6) Heterostylum pallipes Bigot, 1892; (7) Heterostylum rufum (Oliver, 1789); 8-14. Abdomen, dorsal view; 15. Head, dorsal view: (8) Heterostylum evenhuisi Cunha \& Lamas, 2005; (9) Heterostylum ferrugineum (Fabricius, 1805); (10) Heterostylum haemorrhoicum (Loew, 1863); (11) Heterostylum hirsutum (Thunberg, 1827); (12) Heterostylum maculipennis Cunha \& Lamas, 2005; (13) Heterostylum pallipes Bigot, 1892; (14) Heterostylum rufum (Oliver, 1789); (15) Heterostylum ferrugineum (Fabricius, 1805). 
of dark brown hairs on the center of tergites (Fig. 9); sternites light brown and gray pollinose; sternites I - II with yellowishwhite hairs; sternites III - VI with dark brown hairs.

Genitalia: in lateral view with gonocoxa elongated with rounded apex; epiphallus long, L-shaped apically, surpassing apex of posterior process of gonocoxa; aedeagus with wide base and thin and rounded apex; gonostylus robust, with apical beak-like process (Fig. 17); in dorsal view, lateral aedeagal apodeme short, not surpassing gonocoxal margins (Fig. 16); ejaculatory apodema short, not surpassing gonocoxal limits and not visible in lateral view (Fig. 17).

Female : similar to male, except for: Body length: $14.1-$ $16.3 \mathrm{~mm}$; wing length: $14.4-17.6 \mathrm{~mm}$. Frons with reddish-brown hairs; halter stem brown and knob dark brown. Spermathecae (Fig. 25): circular, with well delimited base and longitudinal axis about $1 / 3$ length of sperm pump; furca "U" shaped, with lateral processes enlarged and pointed apically; spermathecal ducts twice as long as sperm pump; sperm pump placed in the middle $2 / 4$ of the spermathecal duct.

Notes: New distribution record for the Brazilian state of Goiás.

Examined Material: BRAZIL, Goiás: Goiânia, 20-III-1962, 1 female, F. M. Oliveira (DZUP); Mato Grosso: Cerrado ( $\left.12^{\circ} 50^{\prime} \mathrm{S}, 51^{\circ} 47^{\prime} \mathrm{W}\right)$, 10-II-1968, 1 male, 1 female, O. W. Richards (BNHM); Murtinho, I1930, 1 male, R. Spitz (DZUP); Murtinho, XII-1929, 1 female (637), R. Spitz (MNRJ); Dourado, 1 female (950) (MNRJ); Xavantina, 02-IV1953, 1 female (633), Malvarenga (MNRJ); BOLIVIA, El Carmen, 27II-1954, 1 female, C. Gans \& F. Pereira (DZUP); El Carmen, II-1955, 1 male (634), Comissão I.O. Cruz (MNRJ).

Distribution: Bolivia: El Carmen; Brazil: Bahia, Ceará, Goiás (Goiânia), Mato Grosso (Cerrado, Dourado, Murtinho), Roraima, São Paulo; British Virgin Is.; Paraguay; Porto Rico; U.S. Virgin Is.

\section{Heterostylum haemorrhoicum (Loew, 1863)} (Figs. 3; 10; 18; 19)

Bombylius haemorrhoicus Loew, 1863: 300 [description]; Loew, 1864:184 [redescription].

Bombylius semirufus Loew, 1872a: 78 [description]; Loew, 1872b: 254 [redescription]; Painter, 1930: 1,2 [redescription].

Heterostylum haemorrhoicum; Painter, 1930: 2 [redescription]; Hull, 1973: 140 [list of species]; Painter et al., 1978: 5 [catalogue]; Evenhuis \& Greathead, 1999: 156 [catalogue]; Cunha \& Lamas, 2005: 24 [key to Brazilian species].

Male: Body length: $12.3 \mathrm{~mm}$; wing length: $10.3-11.7 \mathrm{~mm}$.

Head: holoptic, frons dark brown and light brown pollinose, with brown hairs; ocellar tubercle dark brown and light brown pollinose, with sparse dark brown bristles; face light brown pollinose, smoothly projected, with dark brown hairs; inferior oral margin white pollinose, genae light brown pollinose, both with brown pile; antennae dark brown, scape light brown pollinose with brown bristles, twice as long as pedicel; pedicel light brown pollinose with short dark brown bristles on outer surface; flagellum dark brown, with one flagellomere, twice as long as scape, and an apical style; proboscis dark brown projecting beyond the oral margin by $4 / 5$ of its length; palpus dark brown, 1/9 of proboscis length, with brown hairs; occiput dark brown with dark brown hairs on upper half and brown on the inferior one.

Thorax: mesonotum dark brown, with dark brown hairs; scutellum dark brown with dark brown pile and dark brown bristles on posterior margin; supra alar callus with sparse strong brown bristles and postalar callus with a row of strong dark brown bristles; pleurae light brown; anepisternum entirely covered by long brown hairs; katepisternum with brown hairs; anepimeron, meropleurite and laterotergite bare; metepisternum with brown hairs; calypter with tuft of brown hairs; halter stem yellowish-brown and knob brown with white apex.

Legs: brown with anterior surface darker apically; coxae with long brown pile; femora with dark brown apex, brown scales and long light brown pile on ventral surface; femur III with a row of dark brown bristles on apical 2/3 of anteroventral surface and small dark brown bristles on apex of dorsal surface; tibiae with scattered brown bristles and apical ones; tarsi with brown bristles on ventral surface; pulvilli light brown $1 / 2$ as long as claws.

Wing (Fig. 3): largely hyaline, brownish at extreme base, brown alulae and brown costal cell; R4 conspicuously sinuous; $r-m$ crossvein at $1 / 2$ of discal cell and cup cell open on wing margin by $1 / 2$ length of $r-m$ crossvein.

Abdomen: tergites dark brown; tergite I with brown hairs dorsally and dark brown laterally; tergites II - VI with dark brown hairs dorsally and long orange hairs laterally; sternites dark brown (Fig. 10); sternites I - II with brown hairs; sternites III - VI with dark brown hairs.

Genitalia: in lateral view with gonocoxa elongated with rounded apex; epiphallus long, L-shaped apically, surpassing apex of posterior process of gonocoxa; aedeago with wide base and thin and pointed apex; gonostylus robust, with apical beak-like process (Fig. 19); in dorsal view, lateral aedeagal apodeme short, not surpassing gonocoxal margins (Fig. 18); ejaculatory apodema short, not surpassing gonocoxal limits and not visible in lateral view (Fig.19).

Notes: One specimens with head missing. New distribution record for Dominican Republic.

Female : Unknown

Examined Material: DOMINICAN REPUBLIC, St. Domingo, Sweedie, 2 males (55.1) (BNHM). Haiti.

Distribution: Cuba; Dominican Republic: Santo Domingo;

\section{Heterostylum helvolum Hall \& Evenhuis, 1981}

Heterostylum helvolum Hall \& Evenhuis, 1981: 171 [description], 176 [key]; Evenhuis \& Greathead, 1999: 156 [catalogue].

Diagnoses: Male-Mesonotum pale, whitish-yellow pilose. 

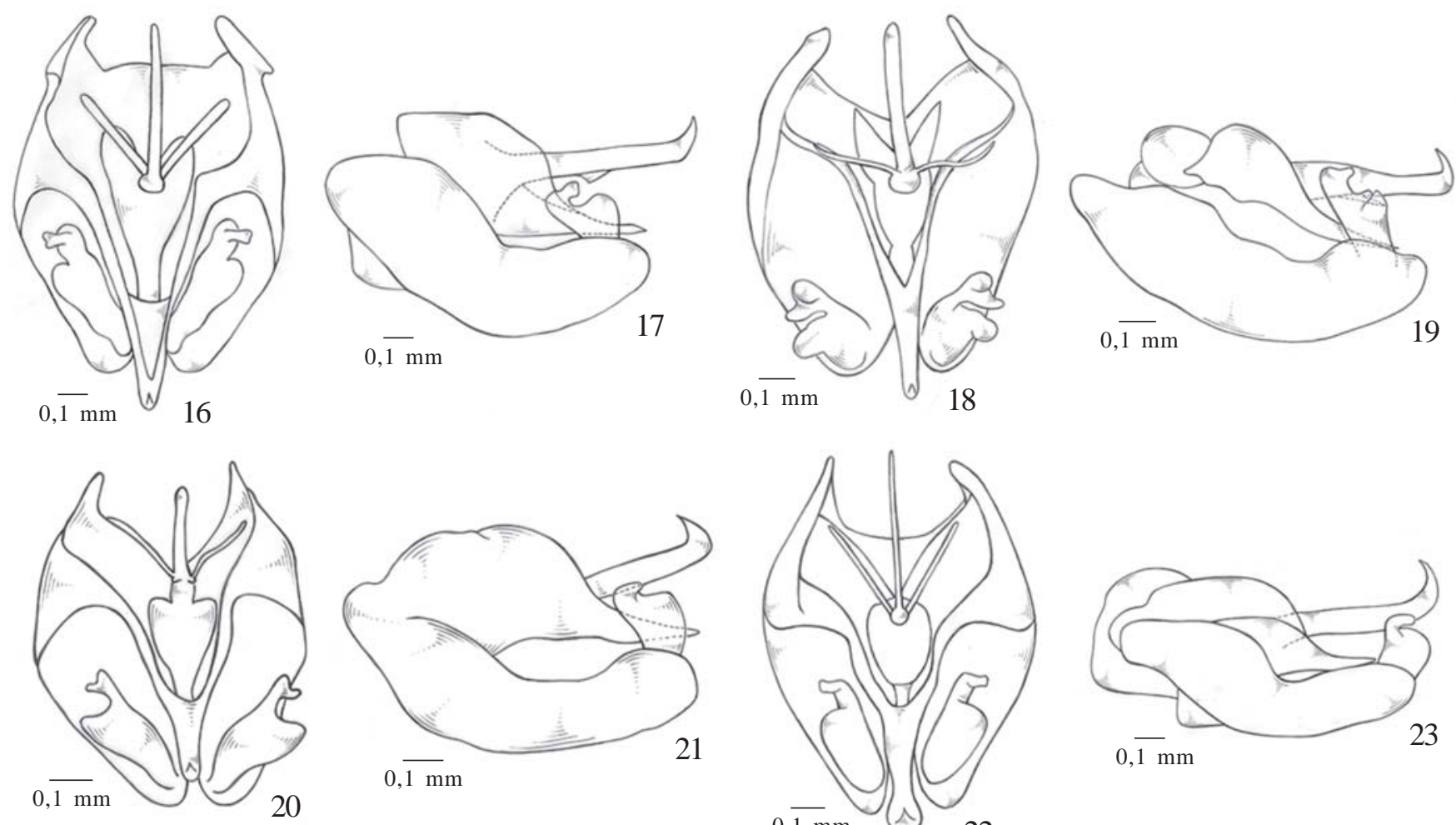

$0, \overline{1 \mathrm{~mm}}$
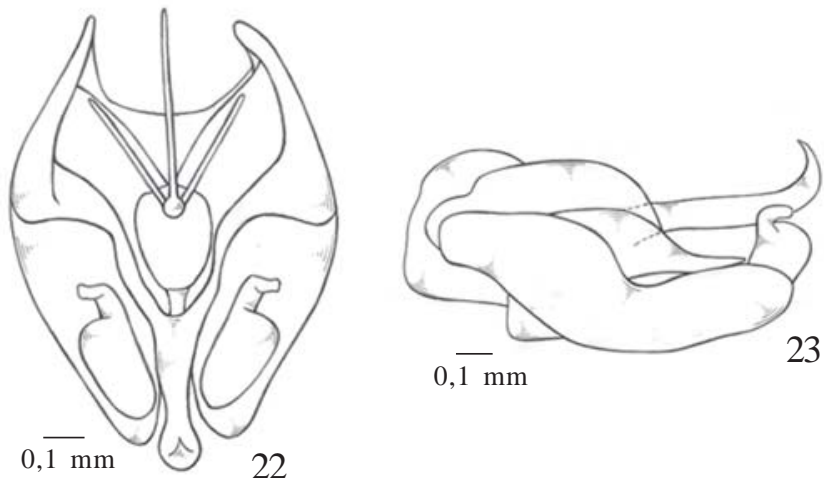

Fig. 16-23. Male Terminalia: (16) Heterostylum ferrugineum (Fabricius, 1805), dorsal view; (17) Heterostylum ferrugineum (Fabricius, 1805), lateral view; (18) Heterostylum haemorrhoicum (Loew, 1863), dorsal view; (19) Heterostylum haemorrhoicum (Loew, 1863), lateral view; (20) Heterostylum hirsutum (Thunberg, 1827), dorsal view; (21) Heterostylum hirsutum (Thunberg, 1827), lateral view; (22) Heterostylum rufum (Oliver, 1789), dorsal view; (23) Heterostylum rufum (Olivier, 1789), lateral view.

Coxae and tips of tarsi black, rest of legs largely flavotestaceous, with basal halves of femora I and II dusky. Wing largely hyaline, lightly brownish at extreme base. Abdominal dorsum black, with posterior margin of tergite III narrowly fulvous; abdominal dorsum pale, whitish-yellow pilose, with tergites II, III and V with dark brown-tipped hairs on posterolateral margins (but not extending across middle of tergites).

Notes: Similar to H. croceum but can be separated by the lighter colored pile on the body, black scape, and dark-tipped hairs on abdominal dorsum.

Distribution: Mexico: Sinaloa, Sonora, Tamaulipas, Zacatecas.

\section{Heterostylum hirsutum (Thunberg, 1827)}

(Figs. $4 ; 11 ; 20 ; 21 ; 26)$

Tanyglossa hirsuta Thunberg, 1827: 67 [description].

Heterostylum flavum Macquart, 1848: 196 (36) [description]; Painter, 1930: 1, 2 [redescription]; Hull, 1973: 140 [list of species]; Painter \& Painter, 1974: 24 [redescription and comments on types].

Heterostylum xanthobasis Curran, 1929: 6 [description]; Painter, 1930: 2 [redescription]; Hull, 1973: 140 [list of species]; Painter \& Painter, 1974: 24 [description and comments on types].

Heterostylum hirsutum; Painter \& Painter, 1974: 22 [redescription and comments on types]; Painter et al., 1978: 5 [catalogue];
Evenhuis \& Greathead, 1999: 156, 157 [catalogue]; Cunha \& Lamas, 2005: 24 [key to Brazilian species].

Male: Body length: $13.4 \mathrm{~mm}$; wing length: $9.2-14.0 \mathrm{~mm}$.

Head: holoptic, frons light brown and gray pollinose, with yellowish-brown hairs; ocellar tubercle dark brown and gray pollinose, with sparse yellowish-brown bristles; face with yellow hairs, smoothly projected; inferior oral margin and genae with yellowish-white pile; antennae with the two distal segments dark brown, scape light brown with dark brown bristles on outer surface, twice as long as pedicel; pedicel with short dark brown bristles in outer surface; flagellum twice as long as scape and pedicel together, with one flagellomere and an apical style; proboscis dark brown projecting beyond the oral margin by $2 / 3$ of its length; palpus yellow, dark brown apically, with long yellow hairs on base and dark brown hairs on apex, 1/5 length of proboscis; occiput yellow with yellowishbrown hairs on upper half and white pollinose with white hairs in the lower one.

Thorax: mesonotum dark brown, with dark brown hairs dorsally and yellowish-brown laterally; scutellum light brown with dark brown bristles on posterior margin; supra alar callus with sparse strong reddish-brown bristles and postalar callus with a row of strong brown bristles; pleurae light brown and gray pollinose; anepisternum entirely covered by long yellow hairs; katepisternum and metepisternum with yellowish-white 
hairs; anepimeron, meropleurite and laterotergite bare; calypter with tuft of light brown hairs; halter stem brown and knob brown with white apex.

Legs: yellowish-brown with anterior surface darker apically; coxae with long yellowish-white pile; femora with dark brown apex, dark brown scales on anterior surface and yellowishwhite pile; femur II with one or two dark brown bristles on anteroventral surface; femur III with two rows of dark brown bristles, the first on basal $2 / 3$ of ventral surface and the second on anteroventral surface, and small dark brown bristles on apex of dorsal surface; tibiae with dark brown apical bristles; tibiae III with dark brown bristles and scales; tarsi with dark brown scales and dark brown bristles on ventral surface, the two apical tarsomeres darker than the others; pulvilli light brown $1 / 2$ as long as claws.

Wing (Fig. 4): largely hyaline, brownish at base in basal $1 / 2$ of costal cell, basal $1 / 2$ of br, basal 2/3 of bm, basal 1/2 of anal and entire alulae; $\mathrm{R} 4$ conspicuously sinuous; $\mathrm{r}-\mathrm{m}$ crossvein at apical half of discal cell and cup cell open on wing margin by $1 / 2$ length of $r-m$ crossvein.

Abdomen: tergite I dark brown, lighter laterally with yellow hairs; tergites II brown with a central dark brown "V" shaped spot; tergite III-IV brown, with a central dark brown stripe; tergites V - VII brown with anterior surface dark brown; tergite II - VII with yellow hairs and a stripe of dark brown hairs on center of tergites; sternite I-VI light brown with yellow hairs (Fig. 11); sternite VII light brown with dark brown hairs.

Genitalia: in lateral view with gonocoxa elongated with rounded apex; epiphallus long, L-shaped apically, surpassing apex of posterior process of gonocoxa; aedeagus with wide base and thin and pointed apex; gonostylus robust, with apical beak-like process (Fig. 21); in dorsal view, lateral aedeagal apodeme short, not surpassing gonocoxal margins (Fig. 20); ejaculatory apodema short, not surpassing gonocoxal limits.

Female: similar to male, except for: Body length: $13.6 \mathrm{~mm}$; wing length: $11.7-14.4 \mathrm{~mm}$. Face and frons brown; scape brown; femur III with row of bristles on apical $2 / 3$ of anteroventral surface; tergites reddish-brown; sternites I-II with yellow hairs; sternites III-VII with brown hairs dorsally and yellow laterally. Spermathecae (Fig. 26): furca "U" shaped, with lateral processes enlarged apically; spermathecae circular, with well delimited base and longitudinal axis about $1 / 3$ length of sperm pump; spermathecal ducts twice as long as sperm pump; sperm pump placed nearly at $1 / 2$ of the spermathecal duct length.

Notes: Only one male and one female had the body length measured. The other specimens were already dissected. Two specimens appears with R4 slightly sinuous, almost straight.

Examined Material: Argentina, La Rioja: Patquia, XII-II - 19321933, 1 male, 1 female, K.J. Hayward (BNHM); VENEZUELA, Federal District: Paroquia Catia La Mar. Escuela Naval. Aprox. $10^{\circ} 36^{\prime} \mathrm{N}$, $67^{\circ} 02^{\prime}$ O; 5 m.s.n.m. Xerofitic vegetation (espinal), 22-IX-1987, 1 female (947), 28-VII-1987, 1 male (948), 18-VIII-1988, 2 males (949) (MNRJ).
Distribution: Argentina: La rioja (Patquia); Brazil; Colombia; Paraguay; Venezuela: Federal District.

\section{Heterostylum maculipennis Cunha \& Lamas, 2005}

(Figs. 5; 12)

Heterostylum maculipennis Cunha \& Lamas, 2005: 28 [description], 24 [key to Brazilian species].

Diagnoses: Male - mesonotum dark brown, with golden pile dorsally and light brown and yellow ones laterally. Legs yellowish brown with darker tarsomeres. Wing hyaline except for tinted brown on base and areas around veins and cells; R4 conspicuously sinuous; $\mathrm{r}-\mathrm{m}$ crossvein at apical half of discal cell. Abdomen with tergites dark brown; tergite I with yellow hairs; tergites II and III with dark brown hairs and two light brown lateral spots, with yellow hairs; tergite IV with dark brown hairs and two light brown spots with yellow hairs; yellow hairs laterally; tergites V and VI with dark brown hairs; tergite VII with dark brown hairs dorsally and yellowish-white hairs laterally (Fig. 12).

Notes: H. maculipennis can be readily distinguished from other species within the genus by the tinted brown wing, not only on its base, but also on areas around veins and cells (Fig. 5).

Examined Material: Holotype male: BRAZIL, São Paulo: Praia Grande, Fazenda Rondonea. II - 1945, M. Carrera, (26.483) (MZSP); Paratypes. BRAZIL, Rio de Janeiro: Nova Friburgo, Mury, 31-I-1965, 2 females, Gred \& Guimarães (MZSP); Itatiaia (700m), 28-XII-1947, 1 female (26.484), J. F. Zikan (MZSP); Angra dos Reis, Japuhyba, I1935, 1 female (638), Dario Mendes (MNRJ); Santa Catarina: Nova Teutonia $\left(27^{\circ} 11^{\prime}\right.$ B. $52^{\circ} 23^{\prime}$ L.) $, 1939,2$ females, Fritz Plaumann (BNHM).

Distribution: Brazil: Rio de Janeiro, Santa Catarina, São Paulo.

\section{Heterostylum pallipes Bigot, 1892}

(Figs. 6; 13; 27)

Heterostylum pallipes Bigot, 1892: 361 [description]; Painter, 1930: 2 [redescription]; Hull, 1973: 140 [list of species]; Painter \& Painter, 1974: 24 [redescription and comments on types]; Painter, et al., 1978: 5 [catalogue]; Evenhuis \& Greathead, 1999: 157 [catalogue]; Cunha \& Lamas, 2005: 24 [key to Brazilian species].

Female: Body length: 12.5 - 13.7mm; wing length: $12.5-$ $13.4 \mathrm{~mm}$

Head: dichoptic, frons yellowish-brown and gray pollinose, with yellow hairs; ocellar tubercle yellowish-brown and gray pollinose, with sparse dark brown bristles; face with gray pollinose, smoothly projected, with yellowish-white hairs; oral margin and genae with yellowish-white pile and gray pollinose; antennae with the two apical segments dark brown, scape yellow with yellow bristles in outer surface, twice as long as pedicel; pedicel with short dark brown bristles in outer surface; flagellum twice as long as scape and pedicel together, with 

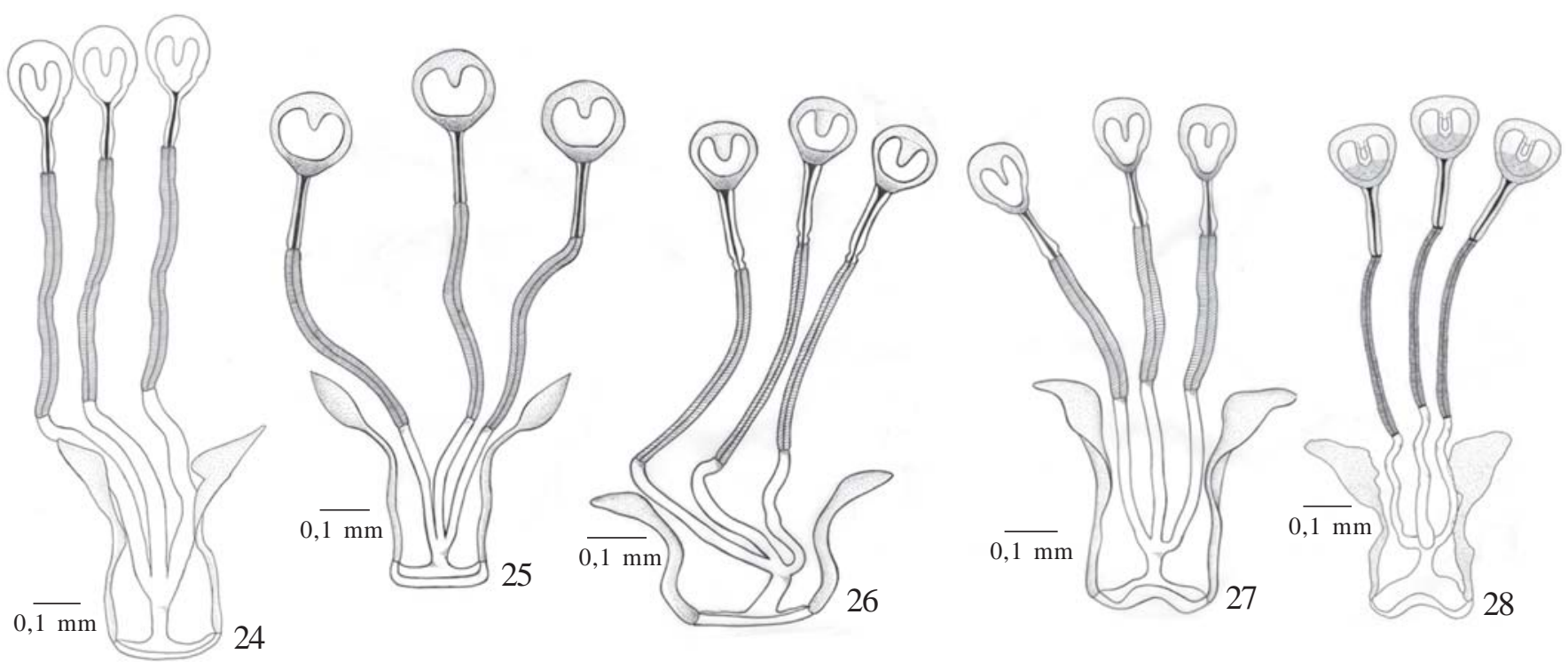

Fig. 24-28. Spermathecae: (24) Heterostylum deani Painter, 1930; (25) Heterostylum ferrugineum (Fabricius, 1805); (26) Heterostylum hirsutum (Thunberg, 1827); (27) Heterostylum pallipes Bigot, 1892; (28) Heterostylum rufum (Oliver, 1789).

one flagellomere and an apical style; proboscis dark brown projecting beyond the oral margin by $2 / 3$ of its length; palpus brown with dark brown apex and yellowish-brown hairs, $1 / 8$ length of proboscis; occiput yellow with yellowish-white hairs.

Thorax: mesonotum dark brown, with yellowish-brown hairs; scutellum brown with dark brown bristles on posterior margin; supra alar callus with sparse strong brown bristles and postalar callus with a row of strong brown bristles; pleurae light brown and gray pollinose; anepisternum, katepisternum and metepisternum with yellowish-white hairs; anepimeron, meropleurite and laterotergite bare; calypter with tuft of yellowish-brown hairs; halter stem brown and knob reddishbrown.

Legs: brown with anterior surface darker apically; coxae with long yellowish-white pile; femora with dark brown apex, brown scales; femur II with three dark brown bristles on ventral surface; femur III with a row of dark brown bristles on apical 2/ 3 of anteroventral surface and small dark brown bristles on the apex of dorsal surface; tibiae with dark brown apical bristles; tibiae I with dark brown bristles on posterior surface; tibiae II and III with dark brown bristles; tarsi with the two apical tarsomeres darker than the others; tarsi I without bristles; tarsi II and III with dark brown bristles on ventral surface; pulvilli light brown $2 / 3$ as long as claws.

Wing (Fig. 6): largely hyaline, brownish at extreme base and alulae; R4 slightly sinuous, almost straight; $\mathrm{r}-\mathrm{m}$ crossvein at $1 / 2$ of discal cell and cup cell open on wing margin by the length of $1 / 2$ the $r-m$ crossvein.

Abdomen: tergite I - II dark brown lighter laterally, with yellowish-brown hairs; tergites III - IV dark brown with brown hairs dorsally and brown with yellowish-brown hairs laterally; tergites V - VII brown with yellowish-brown hairs dorsally and brown hairs laterally; sternites I - II light brown with yellowish-white hairs and gray pollinose (Fig. 13); sternites III - VII light brown with brown hairs and gray pollinose.

Spermathecae (Fig. 27): elliptical, 1/4 longer than wide, with well delimited base and longitudinal axis about 1/2 length of sperm pump; furca "M" shaped, with lateral processes enlarged apically; spermathecal ducts 2.5 times longer than sperm pump; sperm pump placed nearly at $1 / 2$ of the spermathecal duct length.

Variation: Abdominal tergites and legs reddish-brown in one specimen.

Male: similar to female, except for: Wing length: $13.5 \mathrm{~mm}$. Holoptic.

Notes: The unique available male has abdomen apex damaged, which made impossible to describe the genitalia and also to measure the total length. New distribution record for Dominican Republic.

Examined Material: DOMINICAN REPUBLIC, St. Domingo, Sweedie, 1 male, 1 female (55.1); Hearme, 1 female (54.76) (BNHM).

Distribution: Dominicana Republic: Santo Domingo; Haiti.

\section{Heterostylum robustum (Osten Sacken, 1877)}

Comastes robustus Osten Sacken, 1877: 257 [description]; Osten Sacken, 1886: 151 [comments].

Heterostylum robustum; Aldrich, 1905: 237 [redescription]; Painter, 1930: 4 [redescription]; Painter \& Painter, 1965: 411 [catalogue]; Hull, 1973: 140 [list of species]; Painter et al., 1978: 5 [catalogue]; Hall \& Evenhuis, 1981: 173 [redescription], 176 [key]; Evenhuis \& Greathead, 1999: 157 [catalogue].

Diagnoses: Female - First antennal segment vary from pale fulvous to entirely black. Mesonotum dull black, golden-yellow pilose and tomentose. Legs rufotestaceous, tarsi and claws 
black. Wing hyaline, light brown at extreme base. Abdominal tergum black, with posterior margins of most tergites narrowly fulvous except in middle; tergite I pale, yellow to white pilose, white pile in the middle of posterior margins of tergites II-III and on sides of tergites IV-V, black pile on posterior margins of tergites II-III (except in middle) and in middle of tergites IVVII; white tomentose crossbands at basal halves of tergites II$\mathrm{V}$, not extending across dorsum on tergites III-V; lateral margin of abdomen largely white pilose, with black pile at posterior corners of tergites II-III and V-VII.

Distribution: Canada: Alberta; Mexico: Baja California Norte, Baja California Sur, Coahuila de Zaragoza, Guerrero, Morelos, Nuevo León, Puebla, Sinaloa, Sonora, Tamaulipas; USA: Arizona, Oklahoma, Oregon, Texas, Utah.

\section{Heterostylum rufum (Oliver, 1789)}

(Figs. 7; 14; 22; 23; 28)

Bombylius rufus Oliver, 1789: 327 [description]. Bombylius basilaris Wiedemann, 1819: 46 [description]. Tanyglossa deusta Thunberg, 1827: 68 [description]. Bombylius histrio Walker, 1849: 293 [description].

Heterostylum stigmatias Knab, 1913: 110 [description]; Painter, 1930: 3 [redescription]; Hull, 1973: 140 [list of species].

Heterostylum rufum; Painter, 1930: 1,2 [redescription]; Hull, 1973: 140 [list of species]; Painter \& Painter, 1974: 27 [redescription]; Painter et al., 1978: 5 [catalogue]; Evenhuis \& Greathead, 1999: 157 [catalogue]; Cunha \& Lamas, 2005: 24 [key to Brazilian species].

Male: Body length: 10.5 - 16.0mm; wing length: 11.5 $15.1 \mathrm{~mm}$.

Head: holoptic, frons dark brown and gray pollinose, with brown hairs; ocellar tubercle dark brown and gray pollinose, with sparse dark brown bristles; face white pollinose, smoothly projected, with golden hairs; oral margin and genae white pollinose with yellow pile; antennae brown, scape with long brown bristles, twice as long as pedicel; pedicel with short brown bristles on outer surface; flagellum dark brown, twice as long as scape and pedicel together, with one flagellomere and an apical style; proboscis dark brown projecting beyond the oral margin by $4 / 5$ of its length; palpus, with two segments, 1/9 of the proboscis length; first segment yellow, with long yellow hairs on base and short brown bristles on apex, second segment brown, with brown bristles; occiput yellowish-white, gray pollinose, with yellow hairs on the upper half and white on the lower one.

Thorax: mesonotum dark brown, with golden hairs dorsally and yellow laterally; scutellum light brown with golden pile and dark brown bristles on posterior margin; supra alar callus with sparse strong yellowish-brown bristles and postalar callus with a row of strong yellowish-brown bristles; pleurae light brown and gray pollinose; anepisternum entirely covered by long yellow hairs with brown apex; katepisternum with yellow hairs on the anterior half; anepimeron, meropleurite and laterotergite bare; metepisternum with yellow hairs; calypter with tuft of yellow hairs; halter stem light brown and knob yellowish-white.
Legs: yellowish-brown with anterior surface darker apically; coxae gray pollinose with long yellowish-white pile; femora with dark brown apex and yellow scales; femur II with a row of dark brown bristles on the middle $1 / 3$ of ventral surface; femur III with a row of dark brown bristles on apical $2 / 3$ of anteroventral surface and small dark brown bristles on apex of dorsal surface; tibiae with dark brown apical bristles; tibiae I and II and tarsi I and II with sparse dark brown bristles; tibiae III and tarsi III covered by dark brown bristles; tarsi with the three apical tarsomeres darker than the others; pulvilli light brown, as long as claws.

Wing (Fig. 7): largely hyaline, brownish at base in: costal cell and arculus, followed by a dark brown area at basal half of br, almost until apex of bm, basal 1/2 of anal, basal 1/2 of axilary and entire alulae; R4 slightly sinuous, almost straight; r-m crossvein at apical half of discal cell and cup cell open on wing margin by $1 / 2$ of the $r-m$ crossvein length.

Abdomen: tergite I light brown with yellowish hairs; tergites II - III light brown with a central dark brown stripe, dark brown hairs and two lateral spots of yellow hairs; tergite IV light brown with a central dark brown stripe, dark brown and yellow hairs laterally; tergites V - VII with dark brown base and light brown posterior surface; tergite $\mathrm{V}$ with dark brown hairs and a spot of yellow hairs on center; tergite VI - VII with dark brown hairs (Fig. 14); sternite I dark brown, with yellowish-brown hairs; sternites II - VI dark brown with dark brown hairs.

Genitalia: in lateral view with gonocoxa elongated and rounded apex; epiphallus long, L-shaped apically, surpassing apex of posterior process of gonocoxa; aedeagus with wide base and thin apex; gonostylus robust, with apical beak-like process (Fig. 23); in dorsal view, lateral aedeagal apodeme short, not surpassing gonocoxal margins (Fig. 22); ejaculatory apodema surpassing gonocoxal limits and visible in lateral view (Fig. 23).

Female: similar to male, except for: Body length: $10.3-$ 14.8mm; wing length: 11.3 - 15.6mm. Spermathecae (Fig. 28): elliptical, 1/8 wider than long, with well delimited base and longitudinal axis about $1 / 3$ length of sperm pump; furca " $M$ " shaped, with lateral processes enlarged apically; spermathecal ducts twice as long as sperm pump; sperm pump placed nearly at $1 / 2$ of the spermathecal duct length.

Notes: New distribution record for more six Brazilian states: Espírito Santo, Goiás, Mato Grosso, Maranhão, Pará e São Paulo.

Examined Material: BRAZIL, Ceará: Limoeiro, VI-1940, 1 female, Shannon e Alves (DZUP); Barbalha, V-1969, 5 females (952), M. Alvarenga (MNRJ); Espírito Santo: Conceição da Barra, 19-24-VIII1968, 1 male, C.\&C.T. Elias (DZUP); Goiás: Goiânia, 20-III-1962, 3 males, F.M. Oliveira (DZUP); Mato Grosso: Nhambiguara, XI-1960, 2 females, M. Alvarenga (DZUP); Chapada dos Guimarães, Fazenda Buriti, 13-XI-1982, 1 female, Márcio Zanuto e W. Overat (MNRJ); Maranhão: Imperatriz, 21-III-1962, 9 males, 20-II-1962, 18 females, F.M. Oliveira (DZUP); Pará: Serra Norte, road of Fofoca, 20-VIII-1984, 1 female, Márcio Zanuto, 16-IX-1985, 1 male, M.F. Torres, 24-IX-1985, 1 male, M.F. Torres (MPEG); Serra Norte, Serraria, 27-VII-1985, 1 female, suspended trap:1.6m (MPEG); Altar do Chão, rio Tapajos, 1 male 
(54.18), H.W. Bates (BNHM); São Paulo: Sertãosinho, Monteira, III1934, 1 female (636) (MNRJ); British Guiana, 1907, 1 female (1907330), Dr. K.S. Wise (BNHM).

Distribution: Argentina; Brazil: Acre, Espírito Santo (Conceição da Barra), Goiás (Goiânia), Mato Grosso (Nhambiguara, Chapada dos Guimarães), Maranhão (Imperatriz), Pará (Serra Norte, Altar do Chão), São Paulo (Sertãosinho); Guatemala; Guiana; Mexico: Tabasco; Peru, U.S. Virgin Is.

Acknowledgments. The authors thank Dr. David Notton (BNHM) and Dr. Claudio José Barros de Carvalho (DZUP), for loaning us undetermined specimens of Heterostylum to study. Luis Antonio Alves da Costa (MNRJ) for the final art of the illustrations, FAPESP (Fundação de Amparo à Pesquisa do Estado de São Paulo) (Proc. No. 04/09431-5 to CJEL), CNPq (Conselho Nacional de Desenvolvimento Científico e Tecnológico) for the support to CJEL (Proc. No. 470843/ 2004-7) and for MSC (Proc. No. 300370/2004-0).

\section{REFERENCES}

Aldrich, J. M. 1905. A catalog of North American Diptera. Smithsonian Miscellaneous Collections 46: 1-680.

Bigot, J. M. F. 1892. Diptères nouveaux ou peu connus. Annales de la Société Entomologique de France 61: 321-76.

Cunha, A. M. \& C. J. E. Lamas. 2005. Two new species of Heterostylum Macquart (Diptera, Bombyliidae, Bombyliinae) from Brazil. Zootaxa 1006: 23-32.

Curran, C. H. 1929. New Diptera in the American Museum of Natural History. American Museum Novitates 339: 1-13, 2 figs. (Bombyliidae p.6).

Evenhuis, N. L. 1978. Homonymy notes in the Bombyliidae (Diptera) III. Entomological News 89: 247-248.

Evenhuis, N. L. \& D. J. Greathed. 1999. World catalog of bee flies (Diptera Bombyliidae). Backhuys Publishers, Leiden. 756 pp.

Fabricius, J. C. 1805. Systema antliatorum secundum ordines, genera, species adiecta synonymis, locis, observationibus, descriptionibus. C. Reichard, Brunsvigae [=Brunswick].xiv + [15]$372+[1]+30 \mathrm{p}$

Hall, J. C \& N. E. Evenhuis. 1981. Flies of the Nearctic region. Stuttgart: E. Schweizerbart'sche Verlagsbuchhandlung (Nagele U. Obermiller). Volume V, Part 13, Number 2, pp. 162-176.

Hull, F. M. 1973. The beeflies of the world. The genera of the family
Bombyliidae. Bulletin of the United States National Museum 286: $3-687$

Knab, F. 1913. A new Heterostylum from Mexico. (Diptera, Bombyliidae). Insecutor Insecitiae Menstruus 1: 110-111.

Loew, F. H. 1863. Diptera Americae septentrionalis indigena. Centuria quarta. Berliner Entomologisch Zeitschrift 7: 275-326.

Loew, F. H. 1864. Diptera Americae septentrionalis indigena. I. [Centuria 1-5]. A. W. Schadii, Berolini [=Berlin]. 266 p.

Loew, F. H. 1872a. Diptera Americae septentrionalis indigena. Centuria decima. Berliner Entomologisch Zeitschrift 16 : 49-124.

Loew, F. H. 1872b. Diptera Americae septentrionalis indigena. II. [Centuria 6-10]. A.W. Schadii, Berolini [=Berlin]. 300 p.

Macquart, P. J. M. 1848. Diptères exotiques nouveaux ou peu connus. Suite du 2me supplément. Mémoires de la Société Royal des Sciences, de l'Agriculture et des Arts, Lille, 1847(2), 161237.

Oliver, A. G. 1789. Encyclopédie méthodique. Dictionnaire des Insectes. Paris, Pankouke. Vol. 4, 331 pp.

Osten Sacken, C. R. 1877. Western Diptera: Descriptions of new genera and species of Diptera from the region west of the Mississipi and especially from California. Bulletin of the United States Geological and Geographical Survey of the Territories. 3: $\mathrm{n}^{\circ} 2$, pp. 189-354 (Bombyliidae pp. 225-274).

Osten Sacken, C. R. 1886. Diptera [part]. In: Godman, F. D. \& O Salvin, eds., Biologia Centrali-Americana, p. 73-104. Zoologia Insecta. Diptera. Vol. 1. Taylor \& Francis, London.

Painter, R. H. 1930. A review of the Bombyliidae genus Heterostylum (Diptera). Journal of Kansas Entomological Society, 3: 1-7.

Painter, R. H. \& E. M. Painter. 1965 Family Bombyliidae. In: Stone, A.; C. W. Sabrosky; W. W. Wirth; R. H. Foote \& J. R. Coulson, eds., A catalog of the Diptera of America north of Mexico, p. 406446. United States Department of Agriculture, Agriculture Handbook. 276, iv + 1696 p.

Painter, R. H. \& E. M. Painter. 1974. Notes on, and redescriptions of, Types of South American Bombyliidae (Diptera) in European and United States Museums. Kansas State University, Agricultural Experimental Station, Research Publications. 168: 1-322.

Painter, R. H.; E. M. Painter \& J. Hall. 1978. Family Bombyliidae. In: A Catalogue of the Diptera of the Americas South of the United States 38: 1-92.

Thunberg, C. P. 1827. Tanyglossae septendecim novae species descriptae. Nova Acta Upsala. 9: 63-75, 1 pl.

Walker, F. 1849. List of specimens of dipterous insects in collections of the british Museum. Pt. 2, pp. 231-484 (Bombyliidae pp. 235-299.)

Wiedemann, C. R. W. 1819. Brasilianische Zweiflügler. Zoologisches Magazin. 1: 40-56.

Received 13/02/2006; accepted 11/01/2007 